\title{
6. ROCK-MAGNETIC INVESTIGATION OF BASALTS FROM THE SOUTHERN KERGUELEN PLATEAU (LEG 120) ${ }^{1}$
}

\author{
Franz Heider, ${ }^{2,3}$ Christoph Geiss, ${ }^{3}$ David J. Dunlop, ${ }^{2}$ and Hiroo Inokuchi ${ }^{4}$
}

\begin{abstract}
Basalt samples recovered on Ocean Drilling Program Leg 120 from the Kerguelen Plateau were investigated by thermomagnetic analysis, X-ray diffraction, and ore microscopy. The basement samples could be divided into two groups based on Curie temperatures, cell-edge parameters, and optical magnetic mineralogy. Samples from Sites 748 and 750 underwent only low-temperature oxidation and displayed Curie temperatures for the titanomaghemites that ranged from $340^{\circ}$ to $395^{\circ} \mathrm{C}$. The basalts from Sites 747 and 749 mainly experienced high-temperature oxidation. High-temperature oxidation produced titanium-poor titanomagnetites with ilmenite-exsolution lamellae. Curie temperatures of the deuterically oxidized titanomaghemites varied from $490^{\circ}$ to $620^{\circ} \mathrm{C}$.
\end{abstract}

\section{INTRODUCTION}

Basalts from Sites 747,749 , and 750 on the Kerguelen Plateau have a composition that is transitional between a normal Indian Ocean mid-ocean ridge basalt (N-MORB) and an oceanic-island basalt (OIB) (Schlich et al., 1989). These mid-Cretaceous basalts are between 100 and 115 m.y. old, as determined radiometrically with the $\mathrm{K} / \mathrm{Ar}$ method (Whitechurch et al., this volume). The exception among the basement rocks drilled during Leg 120 are the basalts of Site 748 (age, 80 m.y.), which have compositional characteristics similar to alkaline OIB (Schlich et al., 1989). Many previous studies have shown that titanomagnetites $\mathrm{Fe}_{3-x} \mathrm{Ti}_{x} \mathrm{O}_{4}$ with 0.57 $<x<0.67$ are the main magnetic minerals in fresh MORB (e.g., Johnson and Hall, 1978; Petersen et al., 1979). Alkaline basalts from seamounts may have ulvöspinel contents $x$ different from 0.6 (Kono et al., 1980), but the range of differentiation of the Leg 120 basalts is more limited and a composition close to $x=0.6$ is expected.

Fresh titanomagnetites with initial Curie temperatures $\left(T_{c}\right)$ around $150^{\circ} \mathrm{C}$ are often oxidized at low temperatures to titanomaghemites, with $T_{c}$ up to $400^{\circ} \mathrm{C}$ (Ade-Hall et al., 1971; Johnson and Hall, 1978; Petersen et al., 1979). Low-temperature oxidation of titanomagnetite to titanomaghemite has been shown to be a cause for the decrease in intensity of marine magnetic anomalies with increasing age of the ocean floor (Irving, 1970; Prévot and Grommé, 1975; Bleil and Petersen, 1983). Another form of alteration is the high-temperature oxidation of basalts that is common in subaerial flows (Lindsley, 1962; Wilson et al., 1968; Grommé et al., 1969; Ade-Hall et al., 1976; Haggerty, 1976). Although low-T oxidation of titanomagnetite is a single-phase reaction, deuteric oxidation leads to exsolution of different phases, essentially a rhombohedral Ti-rich phase (hemo-ilmenite) and a low-Ti titanomagnetite (spinel structure).

A combination of Curie temperature analysis, cell-edge determination, and ore microscopy was employed in this

\footnotetext{
${ }^{1}$ Wise, S. W., Jr., Schlich, R., et al., 1992. Proc. ODP, Sci. Results, 120: College Station, TX (Ocean Drilling Program).

2 Geophysics Laboratory, Department of Physics, University of Toronto, Toronto, Ontario, M5S 1A7, Canada.

${ }^{3}$ Institut für Allgemeine und Angewandte Geophysik, Ludwig-MaximiliansUniversität, Theresienstrasse 41, 8000 München 2, Federal Republic of Germany.

${ }^{4}$ Department of Earth Sciences, Faculty of Science, Kobe University, Kobe 657, Japan.
}

study to characterize the magnetic minerals in the Leg 120 basalts. The first two of the three methods are necessary to determine the location of the titanomaghemite in the ternary diagram $\left(\mathrm{FeO}, \mathrm{TiO}_{2}\right.$, and $\left.\mathrm{Fe}_{2} \mathrm{O}_{3}\right)$.

\section{METHODS}

Samples for rock magnetic investigations were cut from the same 1-in. drill cores as the cylinders for paleomagnetic studies (Inokuchi et al., this volume). At least one paleo/rockmagnetic sample was collected from the least altered part of each flow unit. We selected 26 basalt specimens from Sites $747,748,749$, and 750 , one or two per lithologic subunit.

Curie temperatures were determined on small rock fragments with a horizontal Curie balance. Saturation magnetizations as a function of temperature, $I_{s}(T)$, were measured during a heating and cooling cycle in air in an applied magnetic field of $0.5 \mathrm{~T}$. Weight loss of the samples during heating and the associated rapid changes in baseline when using a vertical Curie balance often lead to complicated $I_{s}(T)$ curves. These difficulties caused by the evaporation of adsorbed water and release of structural water in clays were not encountered when measuring on a horizontal Curie balance. The Curie temperature values one obtains from an $I_{s}(T)$ curve for a particular titanomaghemite may vary considerably $\left(>100^{\circ} \mathrm{C}\right)$ depending on the method of $T_{c}$ determination (Moskowitz, 1981). We chose a graphic construction that uses the intersection of two tangents to the $I_{s}(T)$ curve above and below $T_{c}$ (Grommé et al., 1969). This graphic method tends to underestimate $T_{c}$ in comparison with the two other methods discussed by Moskowitz (1981). The estimated error in our Curie temperature determinations is $<20^{\circ} \mathrm{C}$ and, therefore, is less than the size of the symbols used in Figure 1. If one has a range of Curie temperatures within a sample that leads to a faster decrease of $I_{s}(T)$, then the graphic method is biased toward the highest $T_{c}$ where $I_{s}(T)$ decreases fastest (see Fig. 2). These two effects of underestimating $T_{c}$ by the graphic method, but determining the maximum $T_{c}$ for a range of $T_{c} \mathrm{~s}$, may partially offset each other.

The magnetic minerals were further characterized with $\mathrm{X}$-ray diffraction. For that purpose, the magnetic particles were separated with a hand magnet from a suspension of the ground sample in water. A powder spectrometer was used with $\mathrm{CuK}_{\alpha}$ radiation and $\mathrm{Si}$ as a calibration standard. The cell edge $a_{\mathrm{o}}$ was calculated for the cubic Fe-Ti spinels from at least three well-defined peaks. Other Fe-Ti oxides (e.g., hematite 


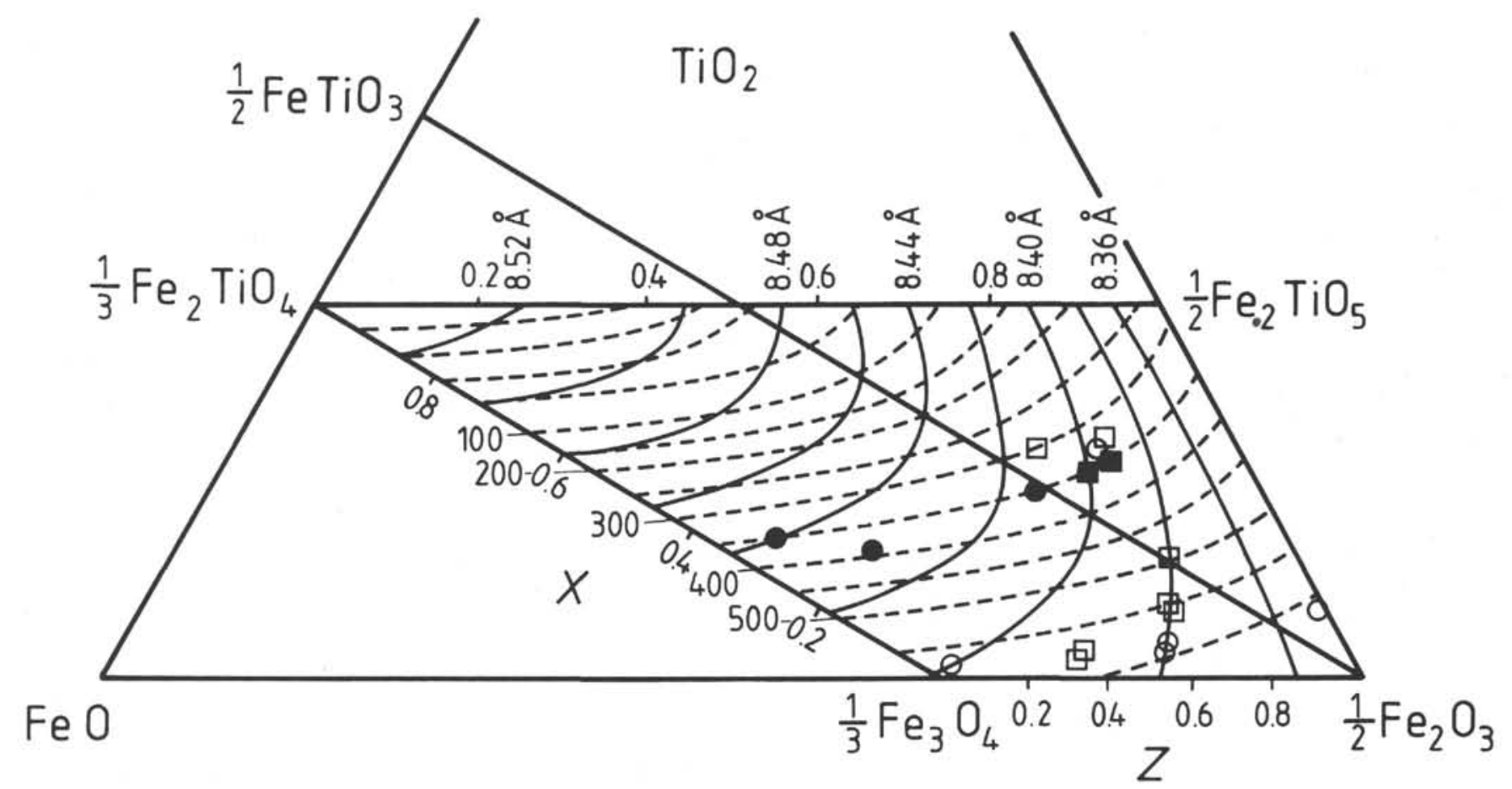

Figure 1. Ternary diagram of the system $\mathrm{FeO}-\mathrm{TiO}_{2}-\mathrm{Fe}_{2} \mathrm{O}_{3}$. The solid contours denote lines of constant cubic cell edge. The dashed contours mark lines of constant Curie temperature $\left({ }^{\circ} \mathrm{C}\right)$. The ulvöspinel content $x$ of titanomagnetites varies from 0 for magnetite to 1 for ulvöspinel. The oxidation parameter $z$ is plotted on the two horizontal lines delimiting the field of titanomaghemites. Symbols: open squares (Site 747C), solid squares (Site 748C), open circles (Site 749C), and solid circles (Site 750B).

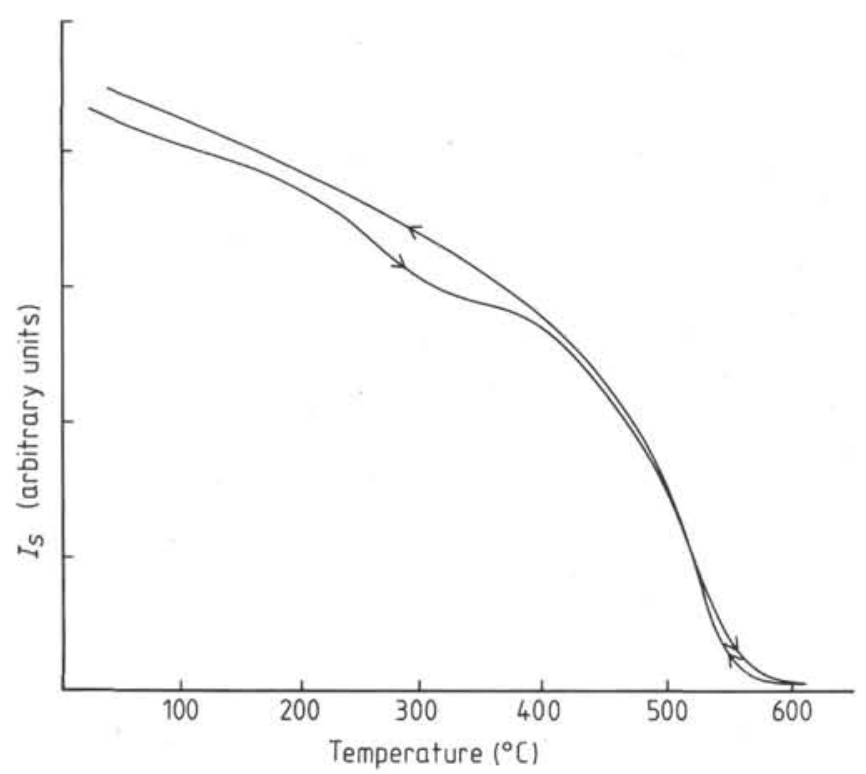

Figure 2. Thermomagnetic curve of Sample 120-747C-12R-2, 11-13 $\mathrm{cm}$.

and ilmenite) were identified by comparing $d$-spacings with the standard ASTM cards. A comparison of cell-edge values determined with the more precise Debye-Scherrer method and with the spectrometric powder technique on Sample 120747C-14R-1, 113-115 cm, yielded identical results for $a_{\mathrm{o}}$. The problems that arise from combining the $T_{c}$ results from whole rocks and the $a_{\mathrm{o}}$ values from magnetic separates will be discussed below.
Polished sections were prepared from selected samples for ore microscopy using a reflected light microscope. We could distinguish between magnetic and nonmagnetic minerals by applying a thin layer of ferrofluid, which is attracted by the magnetic grains in the basalt. The ferrofluid method reveals inhomogeneities in magnetic particles such as those caused by the exsolution of ilmenite lamellae.

\section{RESULTS}

\section{Site 747}

Site 747 lies between the Northern and Southern Kerguelen Plateaus at about $55^{\circ} \mathrm{S}$. In total, about 15 basalt flows with a total thickness of $54 \mathrm{~m}$ were recovered. The flows consisted of partially brecciated and altered aphyric to sparsely phyric basalts. We investigated 13 samples from different lithologic subunits (Schlich et al., 1989) of the basement at Site 747. Brecciated basalts were not used for the paleo/rock-magnetic investigations.

The results from the thermomagnetic and X-ray diffraction (XRD) experiments are summarized in Table 1. Curie temperatures were obtained from $I_{s}(T)$ curves like the one shown in Figure 2 for Sample 120-747C-12R-2, 11-13 cm. The thermomagnetic curve in Figure 2 shows the presence of two magnetic phases with Curie temperatures of $320^{\circ}$ and $550^{\circ} \mathrm{C}$. For Sample $120-747 \mathrm{C}-12 \mathrm{R}-2,11-13 \mathrm{~cm}$, we chose $T_{c}$ as $550^{\circ} \mathrm{C}$ from the main magnetic phase. One of the two magnetic phases was clearly dominant for the other samples at Site 747 with two Curie points, which made the choice of $T_{c}$ easier than for Sample 120-747C-12R-2, 11-13 cm. The cooling curve in Figure 2 returned to a slightly higher saturation magnetization value than before heating because of the conversion of titanomaghemite to more strongly magnetic magnetite.

Samples that had both $T_{c}$ and $a_{\mathrm{o}}$ values were plotted in a $\mathrm{FeO}-\mathrm{TiO}_{2}-\mathrm{Fe}_{2} \mathrm{O}_{3}$ ternary diagram (Fig. 1), with $T_{c}$ and $a_{\mathrm{o}}$ 
Table 1. Summary of Curie temperatures and cell edges.

\begin{tabular}{|c|c|c|c|c|c|c|}
\hline \multirow{2}{*}{$\begin{array}{l}\begin{array}{c}\text { Core, section, } \\
\text { interval }(\mathrm{cm})\end{array} \\
120-747 \mathrm{C}\end{array}$} & \multicolumn{2}{|c|}{$\begin{array}{c}\text { Curie } \\
\text { temperatures }\left({ }^{\circ} \mathrm{C}\right)\end{array}$} & \multirow[t]{2}{*}{$\begin{array}{l}\text { Cell edge } \\
(\AA)\end{array}$} & \multirow[t]{2}{*}{$\begin{array}{l}\text { Number } \\
\text { of peaks }\end{array}$} & \multirow[t]{2}{*}{ Comments } & \multirow[t]{2}{*}{ Alteration } \\
\hline & & & & & & \\
\hline $\begin{array}{l}11 \mathrm{R}-2,19-21 \\
12 \mathrm{R}-1,47-49 \\
12 \mathrm{R}-2,11-13 \\
12 \mathrm{R}-4,27-29 \\
13 \mathrm{R}-3,35-37 \\
13 \mathrm{R}-3,99-101 \\
14 \mathrm{R}-1,09-11 \\
14 \mathrm{R}-1,113-115 \\
15 \mathrm{R}-1,32-34 \\
15 \mathrm{R}-2,86-88 \\
15 \mathrm{R}-3,127-129 \\
16 \mathrm{R}-2,19-21 \\
16 \mathrm{R}-4,19-21\end{array}$ & $\begin{array}{l}330 \\
290 \\
320 \\
310 \\
325\end{array}$ & $\begin{array}{l}\mathbf{4 9 0} \\
\mathbf{5 4 5} \\
\mathbf{5 5 0} \\
\\
570 \\
570 \\
580 \\
\\
\\
595 \\
595 \\
610 \\
610 \\
575\end{array}$ & $\begin{array}{c}8.38 \pm 0.01 \\
8.38 \pm 0.01 \\
8.38 \pm 0.01 \\
8.41 \pm 0.01 \\
- \\
8.39 \pm 0.01 \\
8.38 ? \\
8.39 \pm 0.002 \\
- \\
- \\
- \\
-\end{array}$ & $\begin{array}{l}7 \\
7 \\
5 \\
5 \\
5 \\
1 \\
7 \\
- \\
- \\
- \\
-\end{array}$ & $\begin{array}{l}\text { Ilm } \\
\text { Ilm } \\
\text { Ilm } \\
\text { OM }\end{array}$ & $\begin{array}{l}\text { Moderate } \\
\text { Slight } \\
\text { Slight } \\
\text { Slight } \\
\text { Moderate } \\
\text { Slight-moderate } \\
\text { Moderate } \\
\text { Moderate } \\
\text { Slight-moderate } \\
\text { Moderate } \\
\text { Slight } \\
\text { Slight }\end{array}$ \\
\hline \multicolumn{7}{|l|}{$120-748 \mathrm{C}$. } \\
\hline $\begin{array}{l}79 \mathrm{R}-6,22-24 \\
79 \mathrm{R}-\mathrm{CC}, 15-17\end{array}$ & $\begin{array}{l}340 \\
350\end{array}$ & & $\begin{array}{l}8.40 \pm 0.01 \\
8.39 \pm 0.01\end{array}$ & $\begin{array}{l}3 \\
4\end{array}$ & OM & $\begin{array}{l}\text { High } \\
\text { High }\end{array}$ \\
\hline \multicolumn{7}{|l|}{$120-749 \mathrm{C}$ - } \\
\hline $\begin{array}{l}12 \mathrm{R}-1,24-26 \\
12 \mathrm{R}-4,106-108 \\
12 \mathrm{R}-4,134-136 \\
15 \mathrm{R}-1,108-110 \\
15 \mathrm{R}-5,17-19 \\
15 \mathrm{R}-6,113-115 \\
16 \mathrm{R}-4,132-134 \\
16 \mathrm{R}-7,102-104\end{array}$ & 385 & $\begin{array}{l}585 \\
620 \\
620 \\
530 \\
585 \\
575 \\
610 \\
590\end{array}$ & $\begin{array}{c}8.38 \pm 0.01 \\
8.34 \pm 0.02 \\
- \\
- \\
8.41 \pm 0.02 \\
8.40 \pm 0.01 \\
8.39 \pm 0.01 \\
8.38 \pm 0.01\end{array}$ & $\begin{array}{l}5 \\
4 \\
- \\
3 \\
5 \\
4 \\
4\end{array}$ & $\begin{array}{l}\text { OM } \\
\text { Ilm } \\
\text { Ilm, OM } \\
\text { Ilm }\end{array}$ & $\begin{array}{l}\text { Moderate } \\
\text { High } \\
\text { Slight-moderate } \\
\text { Slight } \\
\text { Slight } \\
\text { Slight } \\
\text { Slight } \\
\text { Fresh }\end{array}$ \\
\hline \multicolumn{7}{|l|}{$120-750 \mathrm{~B}-$} \\
\hline $\begin{array}{l}15 \mathrm{R}-1,62-64 \\
16 \mathrm{R}-5,130-132 \\
17 \mathrm{R}-2,105-107\end{array}$ & $\begin{array}{l}350 \\
350 \\
395\end{array}$ & 580 & $\begin{array}{l}8.41 \pm 0.01 \\
8.44 \pm 0.01 \\
8.42 \pm 0.01\end{array}$ & $\begin{array}{l}4 \\
4 \\
6\end{array}$ & $\begin{array}{l}\text { Ilm } \\
\text { OM }\end{array}$ & $\begin{array}{l}\text { Moderate } \\
\text { Slight } \\
\text { Moderate }\end{array}$ \\
\hline
\end{tabular}

Notes: $T_{c}$ values in bold face are the main Curie temperatures. The uncertainties quoted for the cell-edge values are standard deviations. The number of peaks is from the X-ray diffractogram and is the number that were used for cell-edge calculation. $\mathrm{Ilm}=$ ilmenite, $\mathrm{Hem}=$ hematite, $\mathrm{OM}=$ ore microscopy. The degrees of alteration are from Schlich et al. (1989).

contour lines for synthetic titanomaghemites from Readman and O'Reilly (1972). The contour lines of Readman and O'Reilly (1972) are in reasonable agreement with those of Nishitani and Kono (1983) with a few exceptions. Plotting our results in this fashion assumes that the content of impurity cations in the natural titanomaghemites is small. This assumption is justified based on microprobe analyses of a range of titanomagnetites by Petersen et al. (1979). Adding cations like $\mathrm{Al}$ and/or $\mathrm{Mg}$ to titanomagnetite leads to a decrease in $T_{c}$ (e.g., Petersen, 1976). The results from seven samples from Site 747 fall into two groups in the ternary diagram (open squares in Fig. 1).

Samples 120-747C-12R-4, 27-29 cm, and -14R-1, 113-115 $\mathrm{cm}$, appear to have undergone low-temperature oxidation of an original titanomagnetite (approximate composition $\mathrm{Fe}_{2.4} \mathrm{Ti}_{0.6} \mathrm{O}_{4}$ ), with a Curie temperature of about $160^{\circ} \mathrm{C}$. Sample $120-747 \mathrm{C}-12 \mathrm{R}-4,27-29 \mathrm{~cm}$, was the least altered of all basalts at Site $747 \mathrm{C}$. It had one Curie point at $310^{\circ} \mathrm{C}$, and no indication of a magnetite-like phase with a high $T_{c}$ was given. Sample $120-747 \mathrm{C}-12 \mathrm{R}-4,27-29 \mathrm{~cm}$, comes from the center of a 5.8-m-thick flow and was therefore less affected by alteration. Sample 120-747C-14R-1, 113-115 cm $\left(T_{c}=335^{\circ} \mathrm{C}\right)$, contains anhedral to subhedral homogeneous titanomagnetite/ maghemite grains, which were partially cracked, and, rarely, skeletal grains. There were no signs of nonmagnetic exsolution lamellae in the ferrofluid-coated $\mathrm{Fe}-\mathrm{Ti}$ oxides under the optical microscope at $1250 \times$ magnification. The presence of submicroscopic exsolutions cannot be excluded. Grain sizes ranged from about 8 to $20 \mu \mathrm{m}$. Furthermore, there were nonmagnetic needles among the ore grains-probably ilmenite or rutile-and sporadic red internal reflections from hematite. The ore microscopic observations show mainly homogeneous $\mathrm{Fe}-\mathrm{Ti}$ oxides in Sample 120-747C-14R-1, 113-115 cm. This is in good agreement with the single Curie point of $335^{\circ} \mathrm{C}$, which suggests low-temperature oxidized titanomagnetites as the magnetic remanence carriers.

Usually, Curie temperatures were determined on wholerock chips to obtain $T_{c} \mathrm{~s}$ of all magnetic phases and to reduce oxidation in air. When $T_{c}$ was measured for the magnetic fraction of Sample 120-747C-14R-1, 113-115 cm, we obtained $T_{c}=290^{\circ} \mathrm{C}$, compared with $T_{c}=335^{\circ} \mathrm{C}$ for a whole-rock specimen. This discrepancy in Curie temperatures on the same sample can be explained by the presence of a range of oxidation states (with different oxidation parameters $z$ ). There is a range of particle sizes within a rock, and probably the smaller particles are more oxidized than the larger grains. During the magnetic separation process, the more strongly magnetized and less oxidized large grains with low Curie temperatures are preferentially extracted. The small, more oxidized grains that are excluded during the magnetic separation are more important for the remanence than are the larger grains. Our measured values for $a_{\mathrm{o}}$ form an upper boundary, as cell edges are determined on the less-oxidized large grains. Considering these biases during sample characterization, one would have to plot both $T_{c}$ and $a_{\mathrm{o}}$ at slightly lower values in the ternary diagram $\mathrm{Fe}-\mathrm{TiO}_{2}-\mathrm{Fe}_{2} \mathrm{O}_{3}$ for the whole rock.

Basalts with low Curie temperatures around $320^{\circ} \mathrm{C}$ occur mainly in the upper part of the Site 747 basement section, with 


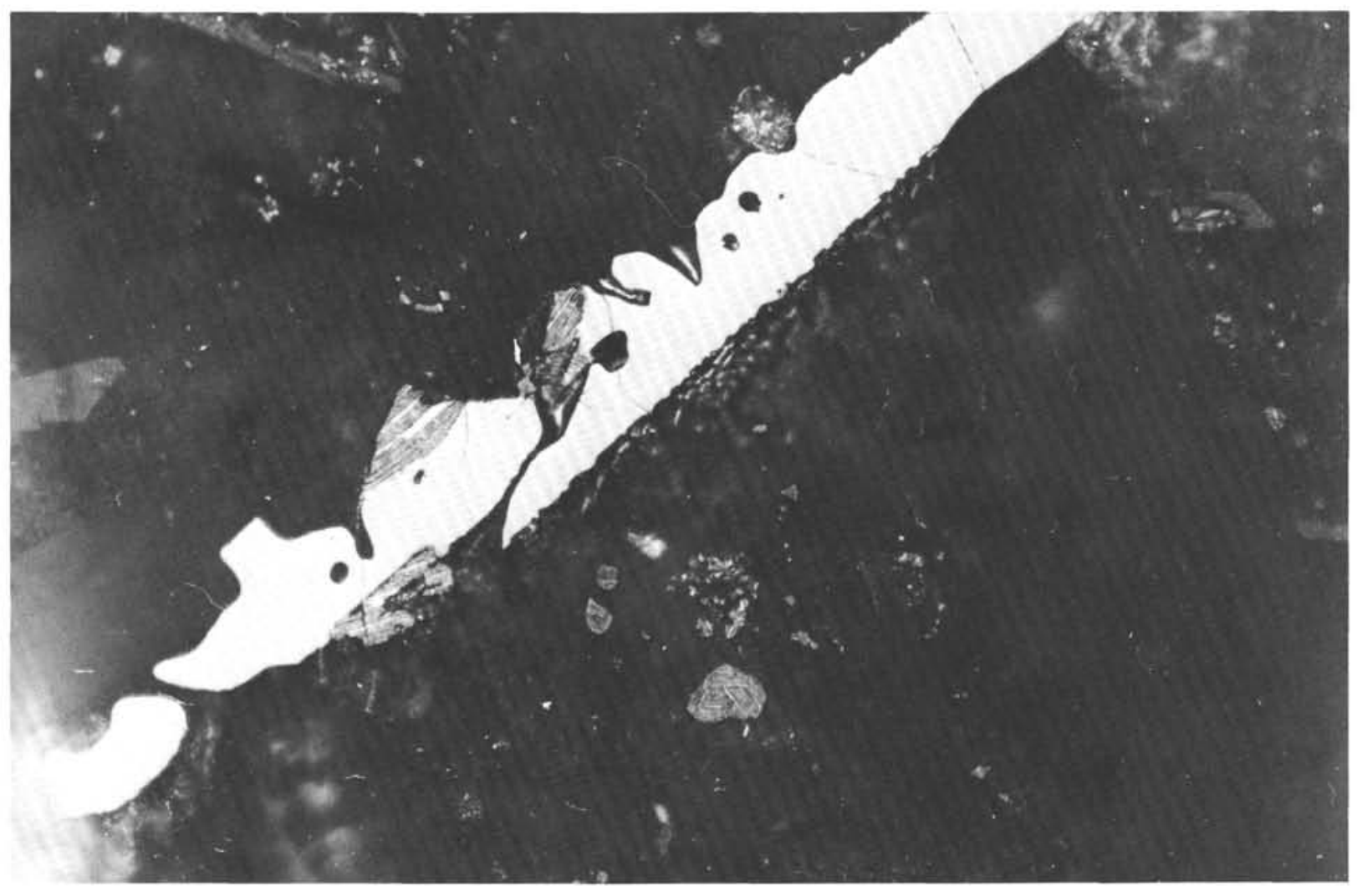

$50 \mu \mathrm{m}$

Figure 3. Polished section of Sample 120-747C-16R-4, 19-21 cm. The ferromagnetic ore grains attract ferrofluid, which forms maze domain patterns. The nonmagnetic ilmenite does not collect ferrofluid. The thin white lines crosscutting the magnetic particles are ilmenite lamellae.

the exception of Sample 120-747C-14R-1, 113-115 cm. Curie temperatures increase continuously for samples with high $T_{c} \mathrm{~s}$ from $490^{\circ} \mathrm{C}$ in Core $120-747 \mathrm{C}-11 \mathrm{R}$ to $610^{\circ} \mathrm{C}$ in Core $120-747 \mathrm{C}$ 16R (Table 1). Ilmenite and hematite peaks were found in the XRDs of some samples with high $T_{c}$. These basalts with high Curie points plot in the ternary diagram (Fig. 1) in the bottom right corner as open squares.

A polished section of Sample 120-747C-16R-4, 19-21 cm, was investigated by ore microscopy as a representative example for the high- $T_{c}$ basalts at Site $747 \mathrm{C}$. We observed anhedral to subhedral magnetite grains with exsolved ilmenite lamellae. A large fraction of the Fe-Ti oxides had diameters around $5 \mu \mathrm{m}$, but grain sizes ranged from 3 to 16 $\mu \mathrm{m}$. These magnetic ore grains occurred in groups near long ilmenite needles. Some of the needle-shaped ilmenite particles had magnetic parts that were covered with ferrofluid. These magnetic subsections of the ilmenite needles were divided by tiny nonmagnetic ilmenite lamellae (Fig. 3). There were very few homogeneous $\mathrm{Fe}-\mathrm{Ti}$ oxide particles without ilmenite lamellae in this sample. The basalts with high Curie points seem to have undergone high-T deuteric oxidation, which typically produces low-Ti titanomagnetites with Ti-rich rhombohedral exsolved lamellae. The high-T oxidation products were subsequently oxidized at low temperatures (maghemitized). During this oxidation process, their compositions move further to the right, roughly parallel with the magnetite-maghemite solid solution line in the ternary diagram (Fig. 1).

\section{Site 748}

Site 748 is located on the Southern Kerguelen Plateau in the western part of the Raggatt Basin. Only the top $3.3 \mathrm{~m}$ of the OIB-like alkaline basalt were paleomagnetically useful at Site 748. The two samples investigated from this site had Curie temperatures $\left(340^{\circ}\right.$ and $\left.350^{\circ} \mathrm{C}\right)$ and cell edges $(8.40$ and $8.39 \AA$ ) characteristic of low-T oxidized basalts (Table 1 and solid squares in Fig. 1),

Ore microscopy with ferrofluid on Sample 120-748C$79 \mathrm{R}-6,22-24 \mathrm{~cm}$, showed dark brown, maze-domain patterns on the ore grains. These magnetic maze patterns are expected for homogeneous titanomaghemites with a stressed surface layer (Fig. 4). There was no indication of ilmenite exsolution lamellae in this sample. Mainly subhedral titanomaghemite grains were quite abundant, with grain sizes ranging from 4 to $25 \mu \mathrm{m}$. There were a few, very thin $(<1 \mu \mathrm{m})$ ilmenite needles and very few red internal reflections, probably caused by hematite. Although the basalts at Site 748 were listed as highly altered in the petrological description (Schlich et al., 1989), the ore phase did not appear to be very altered.

\section{Site 749}

Site 749 lies on the western flank of the Banzare Bank on the Southern Kerguelen Plateau. Five flows consisting of clinopyroxene, plagioclase phyric basalt were recovered. These five flows were probably subaerially erupted in an area of high heat flow (Schlich et al., 1989). Initial high paleoheat 


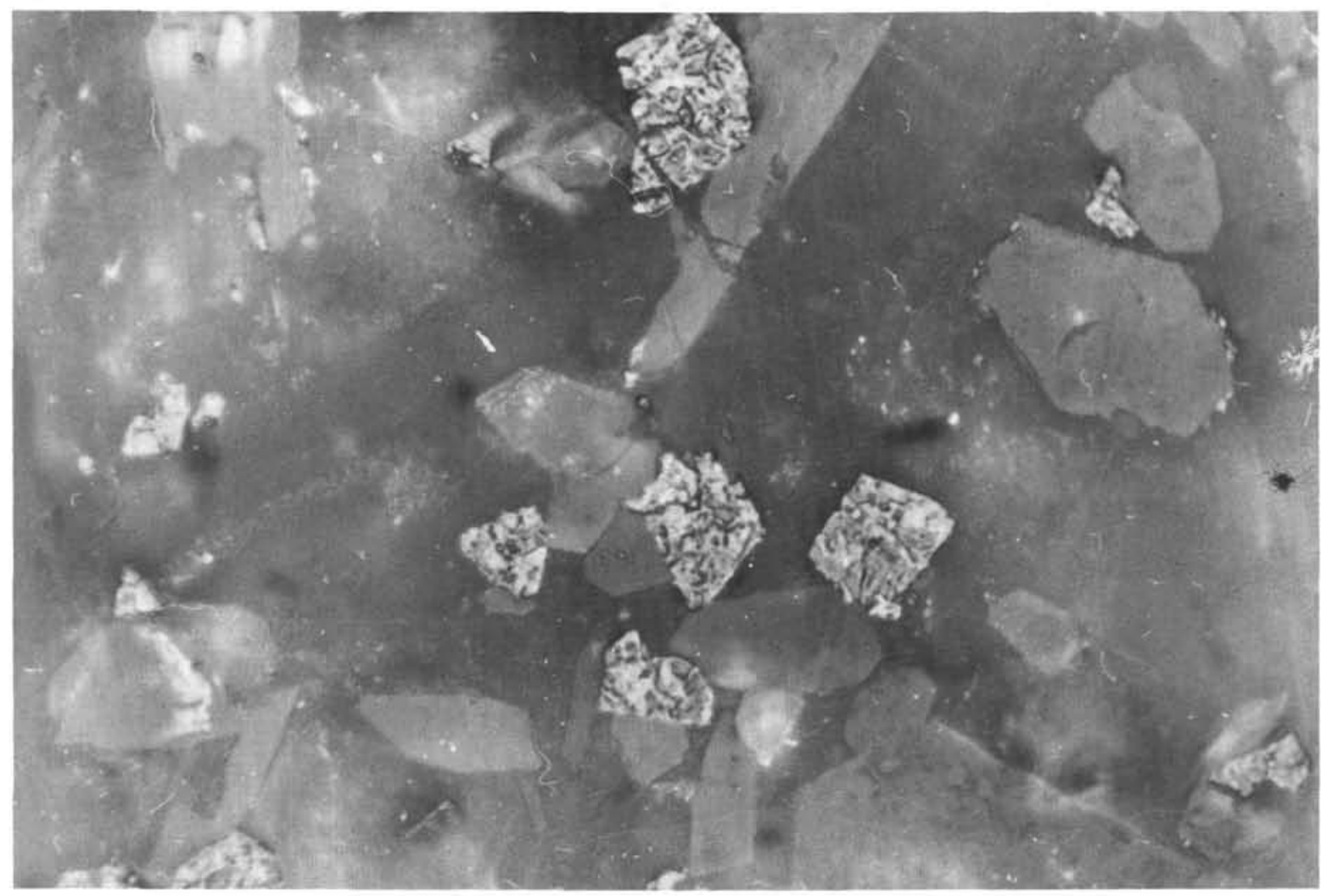

$20 \mu \mathrm{m}$

Figure 4. Polished section of Sample 120-748C-79R-6, 22-24 cm. The ore grains are optically homogeneous titanomaghemites, as evidenced by the continuous maze domain patterns.

flow may have caused the basalts to undergo high-temperature $\left(>600^{\circ} \mathrm{C}\right)$ deuteric oxidation. In agreement with this hypothesis are the high Curie temperatures $\left(530^{\circ}-620^{\circ} \mathrm{C}\right)$ that were found in all basalts from Site 749 . Three samples lie close to the magnetite-maghemite solid-solution series in the ternary diagram (open circles in Fig. 1) based on their $T_{c}$ and $a_{\mathrm{o}}$ values. In these basalts the titanomagnetites were probably first high-temperature oxidized to magnetite and subsequently maghemitized at low temperatures. The ilmenite peaks found in the XRD data (see Table 1) may indicate high-temperature oxidation and associated ilmenite exsolution, but ilmenite could equally well be a primary phase.

Samples 120-749C-12R-1, 24-26 cm, and -16R-4, 132-134 $\mathrm{cm}$, at Site 749 had second Curie temperatures of $385^{\circ}$ and $350^{\circ} \mathrm{C}$, respectively. These two low $T_{c} \mathrm{~s}$ indicate the presence of low-temperature oxidized homogeneous titanomaghemites that did not oxidize at high temperatures.

Samples 120-749C-15R-6, 17-19 cm, and -16R-4, 132-134 $\mathrm{cm}$, should lie outside the ternary diagram (Fig. 1) if one considers their high- $T_{c}$ values and cell-edge data. These difficulties can be reconciled if one takes into account the error in $a_{\mathrm{o}}$ or the bias inherent in our method of determining $T_{c}$ and $a_{\mathrm{o}}$, as discussed above.

In the polished section of Sample 120-749C-12R-4, 134-136 $\mathrm{cm}$, the $\mathrm{Fe}-\mathrm{Ti}$ oxides occur as skeletal grains, with nonmagnetic exsolved lamellae (Fig. 5), indicating high-temperature oxidation. Little ferrofluid is attracted by the magnetic phases, which implies a reduced saturation magnetization compared with magnetite. Particle diameters vary from 1 to $30 \mu \mathrm{m}$, with a mean grain size of about $10 \mu \mathrm{m}$. Ore microscopy of Sample
$120-749 \mathrm{C}-15 \mathrm{R}-6,113-115 \mathrm{~cm}$, shows subhedral to anhedral grains of titanomagnetite with ilmenite exsolution (Fig. 6). The magnetic parts of the exsolved grains attract the colloidal magnetite suspension well, as is evident from the good contrast between the dark maze patterns and the white ilmenite lamellae in Figure 6. Grain diameters range from 2 to $50 \mu \mathrm{m}$. In addition, there are $50-\mu \mathrm{m}$-long ilmenite needles and a few nonmagnetic yellow ore grains-probably sulfides-in this sample. We also observed a few titanomagnetite grains that appeared optically homogeneous judging from continuous maze-domain patterns. In summary, the high Curie temperatures at Site 749 agree well with the microscopic observations, which show magnetite/maghemite grains with ilmenite lamellae crosscutting the grains.

\section{Site 750}

Hole 750B was drilled in the eastern part of the Raggatt Basin on the Southern Kerguelen Plateau. The basalt flows are olivine-hypersthene normative tholeiites in composition. The secondary minerals at this site indicate low-temperature alteration $\left(<50^{\circ} \mathrm{C}\right)$ (Schlich et al., 1989). This indication is compatible with the low Curie temperatures $\left(350^{\circ}-395^{\circ} \mathrm{C}\right)$ (Table 1) that are typical of low-temperature oxidized titanomaghemites. The irreversible thermomagnetic curve of Sample 120-750B-16R-5, 130-132 cm (Fig. 7), shows one magnetic phase with $T_{c}=350^{\circ} \mathrm{C}$ on heating. The second high- $T_{c}$ phase is an inversion product formed during heating in the Curie balance. The ulvöspinel content $x$ is expected to be $\approx 0.35-0.45$, based on $T_{c}$ and $a_{0}$ values from three samples at this site (solid circles in Fig. 1). A ulvöspinel content of about 


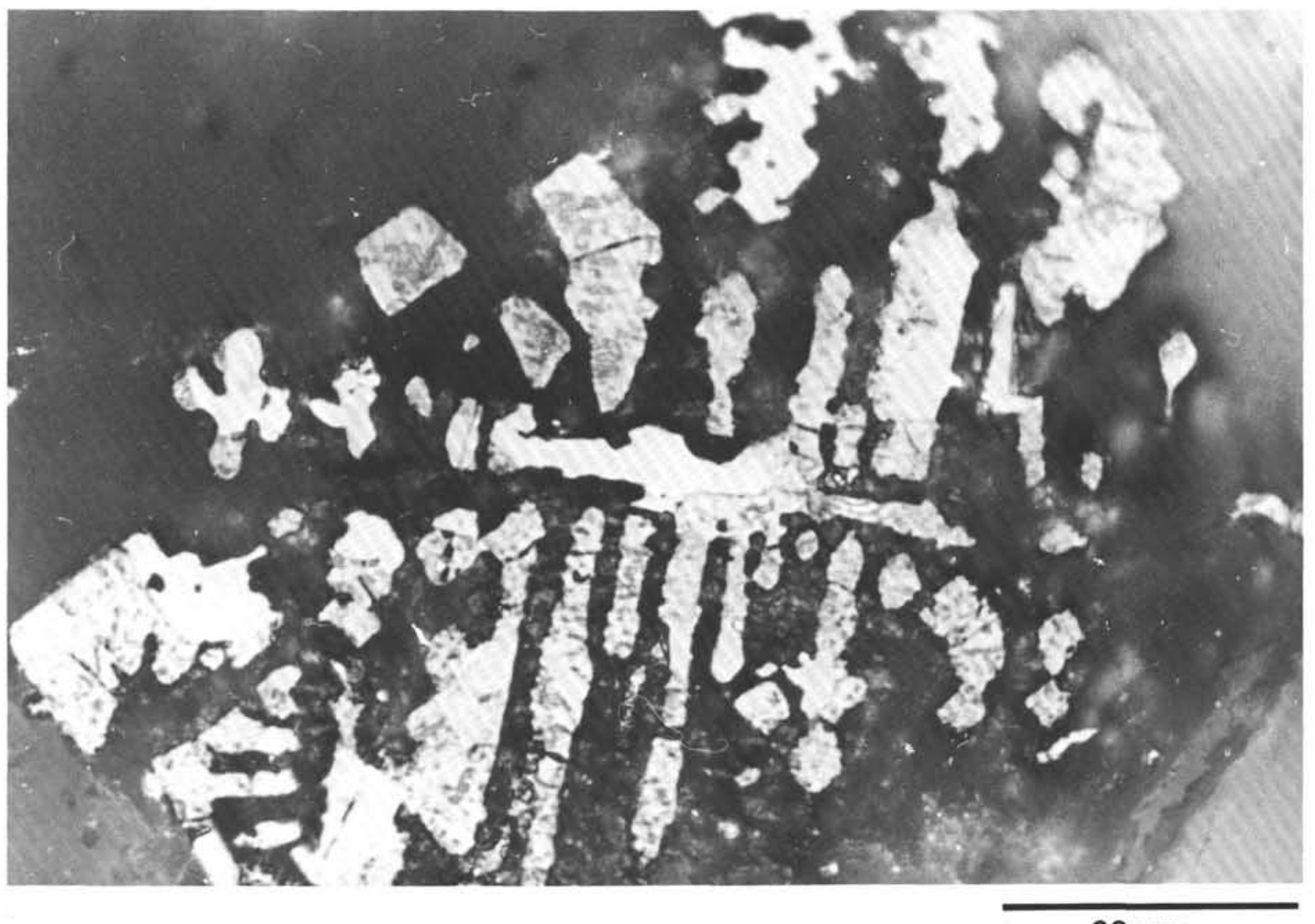

$20 \mu \mathrm{m}$

Figure 5. Sample 120-749C-12R-4, 134-136 cm, covered with magnetic colloid and viewed in reflected light. The skeletal grain possesses nonmagnetic exsolution lamellae. The magnetic areas attract little ferrofluid. Skeletal titanomagnetite particles are typical for quenched rocks.

$40 \%$ is low for tholeiites (see Petersen, 1976). Sample 120$750 \mathrm{~B}-15 \mathrm{R}-1,62-64 \mathrm{~cm}$, has a second $T_{c}$ of $580^{\circ} \mathrm{C}$ and ilmenite peaks in the XRD results. Therefore, this sample was partially high-temperature oxidized.

Under the reflecting light microscope, we observed skeletal homogeneous titanomaghemite grains that attract ferrofluid well (Fig. 8). Some of the fir-tree-shaped titanomaghemites intersect each other. In the polished section of Sample 120-750B-17R-2, $105-107 \mathrm{~cm}$, roughly $95 \%$ of the Fe-Ti oxides appear optically as homogeneous. About $5 \%$ of the titanomaghemites have a few thin ilmenite lamellae, which we interpret as a result of slight deuteric oxidation. There were a few red internal reflections visible in the ground mass, but not in the titanomagnetites. Also visible in Figure 8 are shrinkage cracks, which are characteristic of low-temperature oxidized titanomagnetites (Johnson and Hall, 1978; Petersen and Vali, 1987).

\section{CONCLUSIONS}

The basalts from Site 749 are the most high-temperature oxidized ones among the basement samples from Leg 120 . Because the basalts from Site 749 were probably erupted in a subaerial setting, one can assume that high-temperature oxidation occurred in the beginning. Therefore, the basalts from Hole $749 \mathrm{C}$ are quite likely good paleomagnetic recorders that can preserve strong and stable magnetic remanences (AdeHall et al., 1971). Like the basalts from Site 749, the basalts from Site 747 experienced high-temperature oxidation. Some samples at Site 747 have both a low-temperature and a high-temperature oxidized phase. Low-temperature oxidation takes place far below the Curie point close to ocean bottom temperatures. Cation deficiency increases during progressive low-temperature oxidation because of the removal or replacement of ferrous iron in the titanomagnetite (Hall, 1977). It has been shown that remanent magnetizations do not change their directions much during low-temperature oxidation on the ocean floor (Johnson and Merrill, 1974; Hall, 1977; Özdemir and Dunlop, 1985; Heider and Dunlop, 1987). The directions of the natural remanent magnetizations (NRMs) are useful for paleomagnetism if the high-temperature oxidation happened before the basalt flows of Site 747 cooled. The high Curiepoint phases of basalts from Sites 747 and 749 reveal high unblocking temperatures $\left(T>500^{\circ} \mathrm{C}\right)$ of the natural remanent magnetizations (Inokuchi and Heider, this volume) in accordance with the petrographic observations.

Basalt flows at Sites 748 and 750 underwent low-temperature oxidation with a minimal amount of deuteric oxidation. The oxidation parameter $z$ (e.g., Readmann and O'Reilly, 1972) for the majority of the titanomaghemites ranges from 0.6 to 0.9 (Fig. 1). Based on our rock-magnetic investigations, the basalts from the four basement sites of Leg 120 are suitable for a determination of the paleolatitudes (Inokuchi and Heider, this volume) of the Kerguelen Plateau.

\section{ACKNOWLEDGMENTS}

Financial support and travel funds for F. Heider from NSERC of Canada and from ODP Germany are gratefully acknowledged. We thank Dr. N. Petersen (München) for helpful discussions and his interest in the project. 


\section{REFERENCES}

Ade-Hall, J. M., Fink, L. K., and Johnson, H. P., 1976. Petrography of opaque minerals, Leg 34. In Hart, S. R., Yeats, R. S., et al., Init. Repts. DSDP, 34: Washington (U.S. Govt. Printing Office), 349-362.

Ade-Hall, J. M., Palmer, H. C., and Hubbard, T. P., 1971. The magnetic and opaque petrological response of basalts to regional hydrothermal alteration. Geophys. J. R. Astron. Soc., 24:137-174.

Bleil, U., and Petersen, N., 1983. Variations in magnetization intensity and low-temperature titanomagnetite oxidation of ocean floor basalts. Nature, 301:384-388.

Grommé, C. S., Wright, T. L., and Peck, D. L., 1969. Magnetic properties and oxidation of iron-titanium oxide minerals in Alae and Makaopuhi lava lakes, Hawaii. J. Geophys. Res., 74:52775293.

Hall, J. M., 1977. Does TRM occur in oceanic layer 2 basalts? J. Geomagn. Geoelectr., 29:411-419.

Haggerty, S. E., 1976. Oxidation of opaque mineral oxides in basalts. In Rumble, D., III (Ed.), Oxide Minerals. Mineral. Soc. Am. Short Course Notes, 3:HG1-HG98.

Heider, F., and Dunlop, D. J., 1987. Two types of chemical remanent magnetization during the oxidation of magnetite. Phys. Earth Planet. Inter., 46:24-45.

Irving, E., 1970. The Mid-Atlantic Ridge at $45^{\circ} \mathrm{N}$. XIV. Oxidation and magnetic properties of basalt; review and discussion. Can. J. Earth Sci., 7:1528-1538.

Johnson, H. P., and Hall, J. M., 1978. A detailed rock magnetic and opaque mineralogy study of the basalts from the Nazca Plate. Geophys, J. R. Astron. Soc., 52:45-64.

Johnson, H. P., and Merrill, R. T., 1974. Low temperature oxidation of a single-domain magnetite. J. Geophys. Res., 79:5533-5534.

Kono, M., Clague, D., and Larson, E. E., 1980. Fe-Ti oxide mineralogy of DSDP Leg 55 basalts. In Jackson, E. D., Koizumi, I., et al., Init. Repts. DSDP, 55: Washington (U.S. Govt. Printing Office), 639-652.

Lindsley, D. H., 1962. Investigations in the system $\mathrm{FeO}-\mathrm{Fe}_{2} \mathrm{O}_{3}-\mathrm{TiO}_{2}$. Year Book-Carnegie Inst. Washington, 61:100-106.
Moskowitz, B. M., 1981. Methods for estimating Curie temperatures of titanomaghemites from experimental $J_{s}-T$ data. Earth Planet. Sci. Lett., 53:84-88.

Nishitani, T., and Kono, M., 1983. Curie temperature and lattice constant of oxidized titanomagnetite. Geophys. J.R. Astron. Soc., $74: 585-600$.

Özdemir, O., and Dunlop, D. J., 1985. An experimental study of chemical remanent magnetizations of synthetic monodomain titanomaghemites with initial thermoremanent magnetizations. $J$. Geophys. Res., 90:11513-11523.

Petersen, N., 1976. Notes on the variation of magnetization within basalt lava flows and dikes. Pure Appl. Geophys., 114:177-193.

Petersen, N., Eisenach, P., and Bleil, U., 1979. Low temperature alteration of the magnetic minerals in ocean floor basalts. In Talwani, M., Harrison, C. G., and Hayes, D. (Eds.), Deep Drilling Results in the Atlantic Ocean: Ocean Crust. Am. Geophys. Union, Maurice Ewing Ser., 2:169-209.

Petersen, N., and Vali, H., 1987. Observation of shrinkage cracks in ocean-floor titanomagnetites. Phys. Earth Planet. Inter., 46:197205.

Prévot, M., and Grommé, S., 1975. Intensity of magnetization of subaerial basalts and its possible change with time. Geophys. J. R. Astron. Soc., 40:207-224.

Readman, P. W., and O'Reilly, W. O., 1972. Magnetic properties of oxidized (cation-deficient) titanomagnetites $(\mathrm{Fe}, \mathrm{Ti}, \square){ }_{3} \mathrm{O}_{4}$. J. Geomagn. Geoelectr., 24:69-90.

Schlich, R., Wise, S. W., Jr., et al., 1989. Proc. ODP, Init. Repts., 120: College Station, TX (Ocean Drilling Program).

Wilson, R. L., Haggerty, S. E., and Watkins, N. D., 1968. Variation of paleomagnetic stability and other parameters in a vertical traverse of a single Icelandic lava. Geophys. J., 16:79-96.

Date of initial receipt: 16 January 1990

Date of acceptance: 25 January 1991

Ms 120B-127 


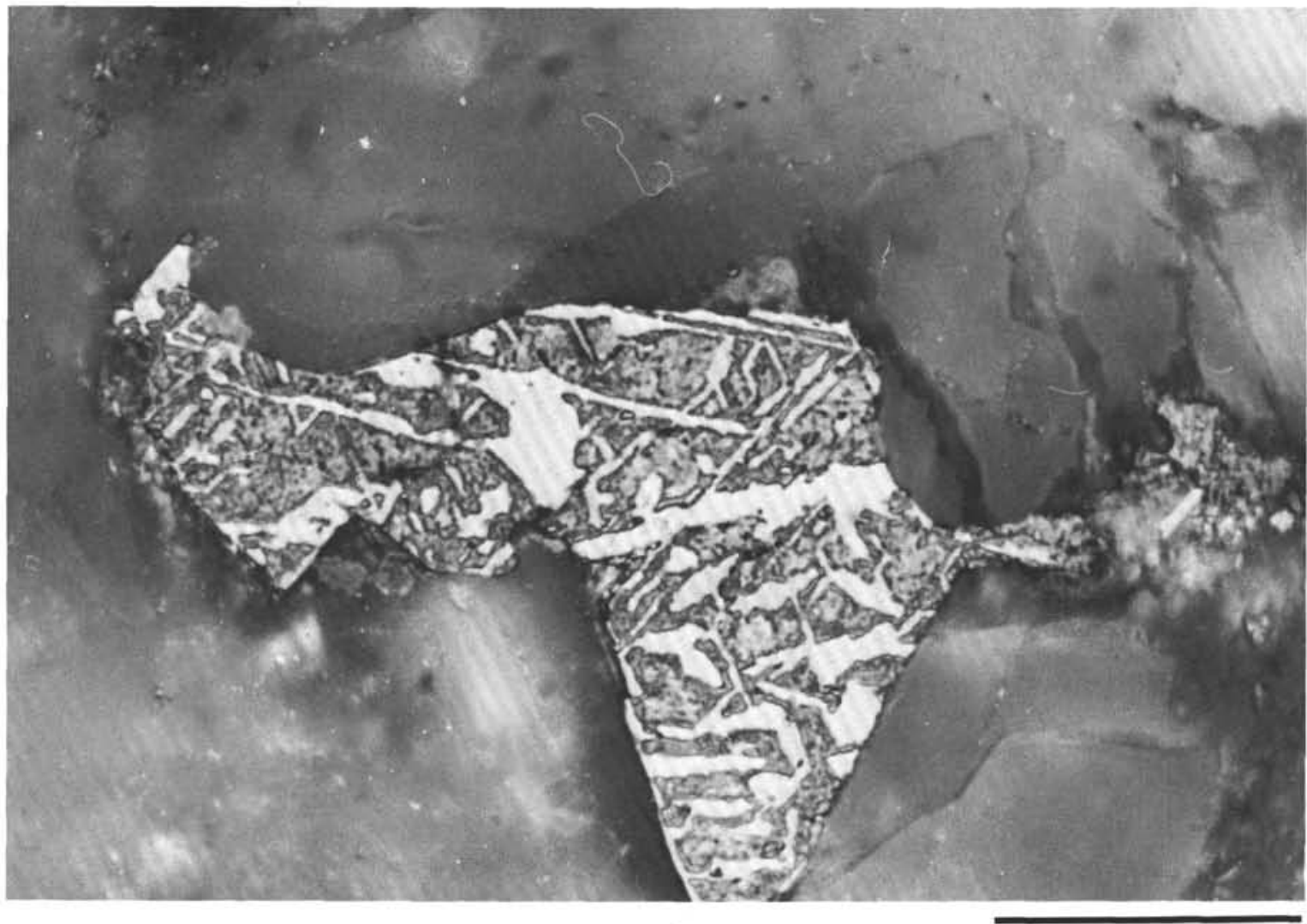

$20 \mu \mathrm{m}$

Figure 6. Polished section of Sample 120-749C-15R-6, 113-115 cm. The grain was high-temperature oxidized. Ilmenite lamellae do not attract ferrofluid and remain white. Ferrimagnetic areas of the grain collect ferrofluid and appear grey.

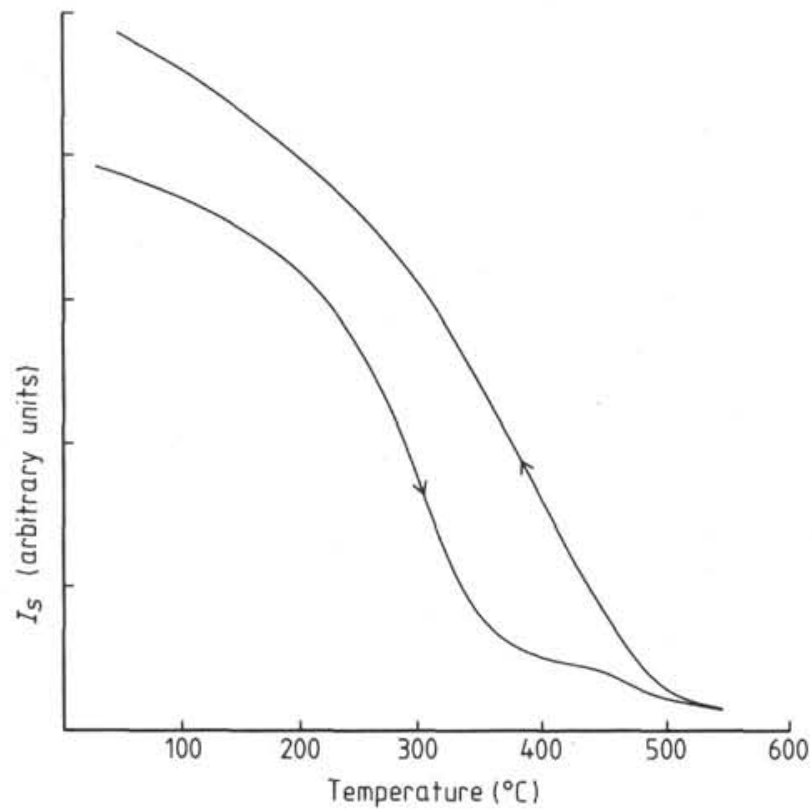

Figure 7. Thermomagnetic curve of Sample 120-750B-16R-5, 130-132 $\mathrm{cm}$. The Curie temperature of $350^{\circ} \mathrm{C}$ and the irreversible cooling curve suggest a low-temperature oxidized titanomagnetite as the main magnetic mineral. 


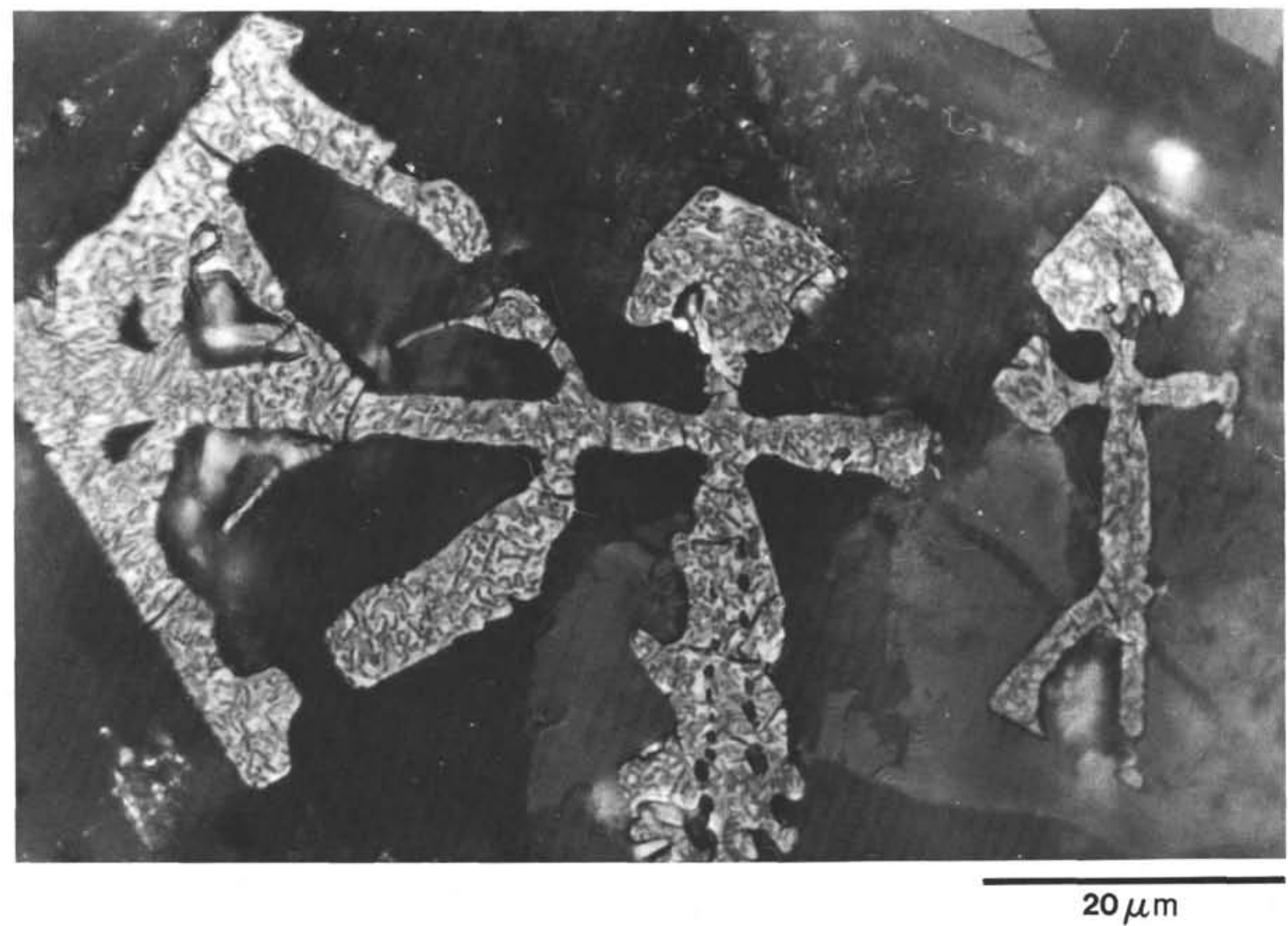

Figure 8 . Sample 120-750B-17R-2, 105-107 cm, has mainly skeletal homogeneous titanomaghemite grains. The lowtemperature oxidized grains have shrinkage cracks. 